International Journal of Management and Sustainability

2014. Vol.s, No.8, pp.484-492

$\operatorname{ISSN}(e): 2306-0662$

$\operatorname{ISSN}(p): 2306-9856$

DOI: $10.18488 /$ journal.11/2014.3.8/11.8.484.492

(C) 2014 Conscientia Beam. All Rights Reserved.

(D) cross Mark

\title{
THE INCLINATION OF INFORMATION AND COMMUNICATION TECHNOLOGY (ICT) STUDENTS TOWARDS ENTREPRENEURSHIP
}

\author{
Mior Nasir Mior Nazri ${ }^{1}$--- Zarinah Hamid ${ }^{2}$--- Herna Muslim ${ }^{3}$ \\ ${ }^{\prime}$ Faculty of Information and Communication Technology, International Islamic University Malaysia Kuala Lumpur, Malaysia \\ ${ }^{2}$ Faculty of Economics and Management Sciences, International Islamic University Malaysia Kuala Lumpur, Malaysia \\ ${ }^{s}$ Faculty of Economics and Management Sciences, International Islamic University Malaysia Kuala Lumpur, Malaysia
}

\begin{abstract}
The lack of innovation in human capital in terms of quality and quantity as well as the significant brain drain has retarded the progress of Malaysia towards becoming a developed country by 2020. In view of this situation, the Ministry of Higher Education (MoHE) of Malaysia has assigned the National Coordination Taskforce for Innovation (NCTI) to develop an innovative human capital (IHC) at tertiary level. One of the key elements in the IHC implementation plan is to enhance the entrepreneurial skills through education. The objective of this study is to investigate the perception and reception of non-business students on entrepreneurship education at the Faculty of Information and Communication Technology (ICT) of International Islamic University Malaysia (IIUM). It examines the level of students' inclination towards becoming entrepreneurs and their interest to learn entrepreneurial skills. The survey utilizes 96 usable responses of third and fourth year students from the faculty. The primary data consists of a set of survey questionnaires which include entrepreneurial intention, attitude towards entrepreneurship, subjective norms of entrepreneurship, perceived behavioral control over entrepreneurship, the influence of faculty on entrepreneurial behavior and the entrepreneurship learning propensity. It provides some insights on the factors influencing ICT students to venture into entrepreneurship. It also suggests measures on the importance of graduates to become successful entrepreneurs and be less dependent on employers.
\end{abstract}

Keywords: Entrepreneurial skills, Entrepreneurship education, ICT students, Entrepreneurial inclination, Attitude towards entrepreneurship, Subjective norms of entrepreneurship.

Received: 21 June 2014/ Revised: 28 June 2014/ Accepted: 2 July 2014/ Published: 7 July 2014

\section{Contribution/ Originality}

Various programs under the Minister of Higher Education (MOHE) of Malaysia have been implemented to attract more students' involvement in entrepreneurship, yet the participation is still low especially from non-business students. Therefore, the reason of conducting this study is to identify the inclination of non-business students in IIUM towards entrepreneurship. It will 
help give awareness to the government and educational institutions on the factors that influence the students' self-employment and subsequently encourage the participation of students, especially non-business students to be involved in entrepreneurship. In fact, a new curriculum policy and resources which fit the needs of future entrepreneurs could be planned in order for entrepreneurship education to be disseminated throughout college campuses. Compared to previous studies which concentrate on Business students, the scope of respondents in this study covers the technical field students in the Faculty of Information and Communication Technology.

\section{INTRODUCTION}

In order to become entrepreneurs, the entrepreneurship education is important as it helps to enhance the entrepreneurship skills of students as well as guidance on how to launch a venture (Lebusa, 2011). According to Jones and English (2004), the curriculum should fulfill two objectives, namely personal and enterprise development objectives. The personal development objectives basically focus on nurturing the entrepreneurial skills and perspective of students, where the students have to compare between the ideal concept of entrepreneur with the skills and attitude that they have. Meanwhile, the enterprise development is focusing on how to identify the opportunity, the process of venturing new business (developing strategy, creating business plan, looking for capital, etc), as well as harvesting strategy. More importantly, these objectives need to be operated simultaneously.

However, in Malaysia entrepreneurship education is always considered as the subject for business students only. Thus, many of non-business students in Malaysia lack of entrepreneurial skills to venture into business. It is found that many of the students have narrow business perspectives and less flexible to branch in other working areas. They foresee themselves as only job seekers and not job creators. Therefore, it is the responsibility of the university to bring in the entrepreneurial education to non-business students as they are in many cases are the originator of product ideas (Ahmad et al., 2004).

As a matter of fact, Frederick et al. (2007) argued that "many of the best ideas in business plan competitions come from non-business major." It shows that there is a possibility that the non-business students could be more creative and innovative entrepreneurs than those who-enter the business school. Therefore, the reason of conducting this study is to understand the entrepreneurship education from the viewpoint of students from non-business background by looking at their perception and reception on the importance of entrepreneurship education. This study is slightly different from the previous studies which typically discussed the entrepreneurship education from the viewpoint of business students. Here, the scope of respondents covered not only those from business field but also from technical field including Communication and Information Technology students.

The purpose of study is to investigate the perception and reception of Faculty of Information and Communication Technology students on entrepreneurship education at International Islamic 
University Malaysia. Based on this objective, the study examines the level of students' inclination towards becoming entrepreneurs and their interest to learn entrepreneurial skills.

This paper is organized as follows. The next section provides the literature review of entrepreneurship education which includes the definition of entrepreneur and entrepreneurship. The discussion also incorporates the motivation and approach in entrepreneurship education as well as the development of entrepreneurship education as a curriculum in higher learning institutions. Section 3 is dedicated for the research methodology and data used in this study. Section 4 is devoted to analysis and findings of the study. This section includes the descriptive statistics and the results of the study. The analysis is based on the research question formed earlier. The last section concludes the outcome of the study.

\section{LITERATURE REVIEW}

According to Lautenschläger and Haase (2011) the formation of new business will benefit the economy through creating more job opportunity, ensure the efficiency and productivity of the economy's welfare, and as an agent in promoting innovation and creativity.

The entrepreneurial education refers "to the process of providing individuals with the ability to recognize commercial opportunities and the insight, self-esteem, knowledge and skills to act on them" (Jones and English, 2004). It has been introduced since 1938 with the development of applied education in entrepreneurship. Then, prior to 1953 , the "small business or entrepreneurship development" course was offered by the University of Illinois. The same course then offered by the University of South Dakota in 1954. In the United States, the first course in entrepreneurship was introduced by engineering professor at MIT, named, Dwight Baumann during 1958. The entrepreneurship education has been disseminated throughout the world by the end of 1960 s (McMullan and Long, 1987).

It was reported that approximately 25 higher learning institution in the U.S offering the entrepreneurship courses by 1970 while in 1980 the number has tremendously increase to more than 150 institutions (McMullan and Long, 1987; Lautenschläger and Haase, 2011). Furthermore, in 1985 the demand for entrepreneurship education has continuously increase where it has been found that there were 245 institutions of higher education with 253 schools offering entrepreneurship courses found in U.S. (McMullan and Long, 1987). By early 1990s, the importance of entrepreneurship education become highly significance in the European, Asian, and African institutions (Frederick et al., 2007; Zakaria et al., 2011).

The awareness on the importance of entrepreneurial education has triggered the policy initiatives like Higher Education Innovation Funds (HEIF), Cambridge-Massachusetts Initiative (CMI), Higher Education Academy (HEA) Subject Centers, National Council for Graduate Entrepreneurship (NCGE), Enterprise Insight (EI) and few others (Gstraunthaler and Hendry, 2011). Furthermore, the research on this field also has been developed with the availability of at least 45 refereed academic journals which are related to enterprise and entrepreneurship. In fact, 
the entrepreneurial education also become the interest of non-business institution whereby new kinds of 'e-ship' like music entrepreneurship, nutrition entrepreneurship, statistics entrepreneurship, nursing entrepreneurship, and engineering entrepreneurship has been launched by campuses outside the Business school (Frederick et al., 2007).

For Malaysia, the development of entrepreneurship education can be analyzed through the event during the pre-independence period. During the colonial of British in Malaya, the economic activity has been segregated according to racial lines, where the Indian migrant workers worked in the rubber plantation, Chinese in tin mines with some in trading, and Malays in the low income agricultural sector. This is to facilitate the administrative operation of British. Upon the independence, Malays as Bumiputera have been given "special rights" in the form of religion, economics, and politics in order to upgrade their economic status and subsequently achieve an equitable society. However, these "special rights" did not manage to reduce the economic inequality between the Malays and other races mainly Chinese, so the New Economic Policy (NEP) was introduced in 1970. The NEP was mainly instituted for the purpose of three objectives, namely; to increase the ownership and participation of the Bumiputera in the corporate sector, to increase the participation of Bumiputera in high-income occupations, and to reduce the income gap as well as eradicating poverty (Ariff and Yanti, 2002).

In order to alleviate poverty and to achieve income equality, the government also established a Bumiputera Commercial and Industrial Community (BCIC) which produced more entrepreneurs and professionals among Bumiputera (Ariff and Yanti, 2002; Malaysia, 2006). In the last decade of 1990s, various entrepreneurship programmes such as National Development Policy (1990-2000), Vision 2020 and the New Economic Model (NEM) which are not confine to Bumiputera only have been initiated by Malaysian government in order to train and develop a self-reliance nation to face the challenges brought by the globalization and the uncertain economic environment (Othman et al., 2012). This is an important agenda as globalization has intensified the economic competitiveness among countries and slowly transforms the nation towards knowledge economy (Zakaria et al., 2011).

The transformation to knowledge economy is in need for the Higher Education Institutions (HEIs) to play an important role in providing entrepreneurship education for the development of entrepreneurial attitudes and skills among the youths (Keat et al., 2011; Zakaria et al., 2011). The participation of younger generation in entrepreneurship could encourage them to become job creators rather than job seekers upon their graduation ((Zakaria et al., 2011) as cited in Jesselyn \& Michell, 2006). In fact, According to Chan et al. (2009), in the case of Malaysia, the youths who choose entrepreneurship career tend to survive from unemployment in the economic crisis. More than that, the entrepreneurship course should not only be taught to business students, but it should include the non-business students as well. This is due to the fact that, "many of the best ideas in business plan competitions come from non-business major."(Frederick et al., 2007). In fact, they are more creative and innovative entrepreneur than those who enter the business school. 
In the case of MMU, for the purpose of nurturing the entrepreneurship attitude and skills among the students, the entrepreneurship course has been offered by the programme called Bachelor of Multimedia (Media Innovation and Entrepreneurship). In fact, all MMU students regardless of their course have to take "Introduction to Cyberpreneurship" subject. Besides MMU, the Universiti Utara Malaysia (UUM) offered four programmes to motivate students towards becoming an entrepreneur, namely; Student Enterprise Program (SEP), Bachelor of Entrepreneurship (a degree program), Basic Entrepreneurship Course and Co-Curricular Entrepreneurship activities (Faudziah and Habshah, 2006). The entrepreneurship programme of UUM is quite different because it merges several entrepreneurship processes into one programme.

The entrepreneurship processes included are "the environmental influences and the processes of planning, researching, and developing entrepreneurial education and training" (Zakaria et al., 2011). Similar to UUM, Universiti Tenaga Nasional also offers degree of entrepreneurship in its Bachelor program. On the other hand, for the case of Universiti Putra Malaysia (UPM), the entrepreneurship course was offered in its Bachelor of Business Administration Programme, while for Universiti Malaya (UM) the course was offered under the Department of Business Strategy and Policy. Some Institutes of Higher Learning offers the entrepreneurship course under the Master of Business Administration (MBA) level (Faudziah and Habshah, 2006).

\section{METHODOLOGY AND DATA}

The study focuses mainly on the perception of students from Faculty of Information and Communication Technology of IIUM towards entrepreneurship education. About 96 usable responses are selected at random from this faculty. The primary data consists of a set of survey questionnaires. These questionnaires are designed to answer the research questions mentioned earlier. In designing the questionnaire, considerations are given to its content, structure, format and sequence. It is being designed in such a way that it is easy for the respondents to complete the questionnaire. Thus the questionnaire generally consists of closed-ended questions for ease of filling it. We conduct pre-tests or pilot studies before the commencement of actual data collection in order to ensure that the objectives of the study and its tools are correct, suitable, reliable and valid. The pilot study is important in order to get feedback as well as constructive comments and suggestions on the design of the questionnaire, time taken to complete the questionnaire, clarity of the instructions and questions as well as the relevancy of the questions posed. In the context of this research, a pilot study was conducted on ten students of IIUM. Based on the feedback received from these respondents, amendments were made and the questionnaire were improved and updated.

Statistical analyses of data were carried out using SPSS version 16.0 through polynomial regression analysis, coefficients of determination (R-squared adjusted values) and observed significance ( $p$-values) in order to study the relationship of the indicators associated with 
entrepreneurship. We adopt a backward elimination method which begins with the entire set of variables and eliminates one insignificant independent variable at each iteration. We also check for high multicollinearity problem which may arise among the independent variables by generating the variance inflation factor (VIF) values and correlation matrix.

\section{ANALYSIS AND FINDINGS}

The survey conducted on 6 December 2012 produced 96 usable responses. The questionnaires were divided into 7 parts where the first part provided information on the respondents' background, the second part consisted of 19 items on entrepreneurial intention, the third part had 11 items on attitude towards entrepreneurship, the fourth part measured 8 items of the subjective norms on entrepreneurship, the next part had 12 items on perceived behavioral control over entrepreneurship, the sixth part consisted of 9 items on the influence of faculty courses on entrepreneurial behavior and the last part had 10 items related the inclination towards learning entrepreneurship.

Table-1. Profile of Respondents

\begin{tabular}{|c|c|c|c|c|}
\hline \multirow[b]{2}{*}{ No. } & \multirow[b]{2}{*}{ Item } & \multirow[b]{2}{*}{ Characteristics } & \multicolumn{2}{|c|}{ Sample } \\
\hline & & & Frequency & Percentage \\
\hline \multirow[t]{2}{*}{1} & \multirow[t]{2}{*}{ Gender } & Male & 30 & 31.3 \\
\hline & & Female & 66 & 68.8 \\
\hline \multirow[t]{2}{*}{2} & \multirow[t]{2}{*}{ Nationality } & Local & 81 & 84.4 \\
\hline & & International & 15 & 15.6 \\
\hline \multirow[t]{3}{*}{3} & \multirow[t]{3}{*}{ Level of study } & Third year & 40 & 42.1 \\
\hline & & Final year & 53 & 55.8 \\
\hline & & Others & 2 & 2.1 \\
\hline \multirow[t]{2}{*}{4} & \multirow{2}{*}{$\begin{array}{l}\text { Working/entrepreneur-ship } \\
\text { experience(s) }\end{array}$} & Yes & 61 & 63.5 \\
\hline & & No & 35 & 36.5 \\
\hline \multirow[t]{2}{*}{5} & \multirow{2}{*}{$\begin{array}{l}\text { Involvement } \\
\text { entrepreneurship } \\
\text { programmes }\end{array}$} & Involved & 32 & 33.3 \\
\hline & & Not Involved & 64 & 66.7 \\
\hline \multirow[t]{2}{*}{6} & \multirow[t]{2}{*}{ Family business background } & Involved & 62 & 64.6 \\
\hline & & Not Involved & 34 & 35.4 \\
\hline
\end{tabular}

A summary of the profile of the respondents is shown in Table 1. It depicts that $31.3 \%$ of the respondents are male while $68.8 \%$ are female. This can be expected considering the fact that a high percentage of the IIUM students are female. It can also be seen that most of the respondents are local $(84.4 \%)$ as compared to international $(15.6 \%)$. Since the focus of the research is to study the inclination of third and fourth year students towards entrepreneurship, $97.7 \%$ of the respondents' level of study falls into these 2 categories. They have some kind of working experience whereby they either work on part-time basis or involve with family business. However, two-thirds (66.7\%) of the respondents have no prior involvement with entrepreneurship programmes.

The empirical model for entrepreneurial intention is specified as follows:

$$
E I=\alpha_{0}+\alpha_{1} A T T+\alpha_{2} S N+\alpha_{3} P B C+\alpha_{4} K C I+\alpha_{5} E L P+\epsilon
$$


where

$E I=$ entrepreneurial intention

$A T T=$ attitude towards entrepreneurship

$S N=$ subjective norms of entrepreneurship

$P B C=$ perceived behavioral control over entrepreneurship

$K C I=$ the influence of faculty courses

$E L P=$ entrepreneurship learning propensity

$\epsilon=$ error term

Table-2. Parameter Estimates of Entrepreneurial Intention

\begin{tabular}{llll}
\hline & Model 1 & Model 2 & Model 3 \\
\hline Constant & 1.707 & 1.646 & 1.525 \\
\hline ATT & $.480^{* * *}$ & $.469^{* * *}$ & $.458^{* * *}$ \\
\hline SN & $.130^{*}$ & $.122^{*}$ & $.121^{*}$ \\
\hline PBC & .053 & .052 & .040 \\
\hline KCI & -.054 & -.058 & \\
\hline ELP & -.035 & & .490 \\
\hline $\mathrm{R}^{2}$-adjusted & .482 & .488 & \\
\hline
\end{tabular}

Notes: ***,**, and $*$ indicate significance at the $1 \%, 5 \%$, and $10 \%$ levels, respectively.

These output are based on the average value (Total value/ no. of items)

The results from the regression analysis of the sample data are presented in Table 2 . We started with 5 explanatory variables but we decided to remove two insignificant variables, namely KCI and ELP and rerun the multiple regression analysis for the second time and third time. With the increased $\mathrm{R}^{2}$-adjusted from 0.482 to 0.490 for model 1 and model 3, respectively, we conclude that model 3 is the best model that explains the entrepreneurial intention among the ICT students. The first two variables, namely attitude towards entrepreneurship and subjective norms of entrepreneurship are significant at $1 \%$ and $10 \%$, respectively. These results are consistent with the previous studies which found that these two factors are significant and positively influenced students to venture into entrepreneurship.

The Cronbach's Alpha test which measures the reliability of the data is performed. The values of Cronbach's Alpha for 19 items that represent the entrepreneurial intention, 11 items on attitude towards entrepreneurship, 8 items on subjective norms, 12 items on perceived behavioral control, 9 items on the faculty influence and 10 items on learning propensity are $0.762,0.815$, $0.804,0.895,0.727$ and 0.681 , respectively. Next, to measure the sampling adequacy the KaiserMeyer-Olkin (KMO) is performed for these items and they registered large values. These large numbers indicate that factor analysis of the variables is a good idea. In addition, the Bartlett's Test of Sphericity which is used to test the null hypothesis that the variables in the population correlation matrix are uncorrelated is also rejected. Thus we conclude that the strength of the 
relationship among variables is strong and it is reasonable to proceed with factor analysis in our future research.

\section{CONCLUSION}

This research shows that non-business students, specifically those with ICT background have the interest to become entrepreneurs after they graduated from the university. They need entrepreneurship education to become successful entrepreneurs and be less dependent on employers. The factors that influence students' entrepreneurial inclination include attitude towards entrepreneurship and subjective norms of entrepreneurship.

This research also found that there is a lack of awareness on the needs of non-business students towards entrepreneurship education. They have to be convinced that learning entrepreneurship will give additional value to them and it will increase their levels of confidence to venture into business after graduation. The faculty must play an important role in promoting the entrepreneurship education by integrating the theoretical and practical in its teaching methods. They have to align the curriculum structure so as to ensure that it is in line with the objectives of producing more successful entrepreneurs.

Funding: This study received no specific financial support.

Competing Interests: The authors declare that they have no competing interests.

Contributors/Acknowledgement: All authors contributed equally to the conception and design of the study.

\section{REFERENCES}

Ahmad, F.S., D.R. Baharun and S.H.A. Rahman, 2004. Interest in entrepreneurship: An exploratory study on engineering and technical students in entrepreneurship education and choosing entrepreneurship as a career. RMC Project: Vot 71790, University Teknologi Malaysia. pp: 44.

Ariff, M.M. and S.A. Yanti, 2002. Strengthening entrepreneurship in Malaysia. Available from www.mansfieldfdn.org/programs/entrepreneurship.htm [Accessed June 20th, 2012].

Chan, K.L., S. Selvadurai and B. Abdul Hamid, 2009. Malay youth entrepreneurship in Malaysia: An empirical update. Malaysian Journal of Society and Space, 5(2): 55-67.

Faudziah, Z.A. and B. Habshah, 2006. Entrepreneurship education: The case of universiti Utara Malaysia. Available from http://wmssoros.mngt.waikato.ac.nz/NR/rdonlyres/ekigitceflrgnvok3qgu5fvlvg72koxaqvtt3wgcf3j3ut3oom mu2x5i4va7db2wpkuhi22rvtr22k/Resource16.pdf [Accessed June 25, 2012].

Frederick, H.H., D.F. Kuratko and R.M. Hodgetts, 2007. Entrepreneurship: Theory, process, practice. Victoria, Australia: Thomson.

Gstraunthaler, T. and S. Hendry, 2011. Entrepreneurial and accounting education through action-based learning: The genesis project. Journal of Entrepreneurship Education, 14: 125-146.

Jones, C. and J. English, 2004. A contemporary approach to entrepreneurship education. Education + Training, 46(8/9): 416-423. 
Keat, O.Y., C. Selvarajah and D. Meyer, 2011. Inclination towards entrepreneurship among university students: An empirical study of Malaysian university students. International Journal of Business and Social Science, 2(4): 206-220.

Lautenschläger, A. and H. Haase, 2011. The myth of entrepreneurship education: Seven arguments against teaching business creation at universities. Journal of Entrepreneurship Education, 14: 147-161.

Lebusa, M.J., 2011. Does entrepreneurial education enhance under-graduate students' entrepreneurial selfefficacy? A case at one University of technology in South Africa. China-USA Business Review, $10(1): 53-64$.

Malaysia, 2006. Ninth Malaysia plan 2006-2010. The economic planning unit, Prime Minister's Department, Putrajaya.

McMullan, W. and A.W. Long, 1987. Entrepreneurship education in the nineties. Journal of Business Venturing, 2: 261-275.

Othman, N., N.H. Othman and R. Ismail, 2012. Impact of globalization on entrepreneurship education and entrepreneurial skills in higher education institutions. 2012 2nd International Conference on Economics, Trade and Development. Singapore: IACSIT Press, 36: 84-89.

Zakaria, S., W.F. Wan Yusoff and R.H. Raja Madun, 2011. Entrepreneurship education in Malaysia: Nurturing entrepreneurial interest amongst students. Journal of Modern Accounting and Auditing, 7(6): 615-620.

Views and opinions expressed in this article are the views and opinions of the author(s), International Journal of Management and Sustainability shall not be responsible or answerable for any loss, damage or liability etc. caused in relation to/arising out of the use of the content. 